\title{
春䯣硬膜外神経鞘腫の手術時の留意点
}

\section{Some Pointers for the Surgical Management of Spinal Extradural Schwannomas}

\author{
冨井雅人 $* 1$ 伊藤康信 ${ }^{* 1}$ 沼澤 真 一 *1 \\ 渡邊一夫*1 平野仁崇*2 中川洋*3
}

Masato Tomii, M. D. ${ }^{* 1}$, Yasunobu Itoh, M. D. ${ }^{* 1}$, Shinichi Numazawa, M. D. ${ }^{* 1}$,

Kazuo Watanabe, M. D. ${ }^{* 1}$, Yoshitaka Hirano, M. D. ${ }^{* 2}$, Hiroshi Nakagawa, M. D. ${ }^{* 3}$

\begin{abstract}
A series of 9 patients with spinal extradural schwannomas (1 neurofibroma and 8 schwannomas) was surgically treated during a 2-year period. The purpose of this article is to present some pointers for the surgical management of spinal extradural schwannomas. The tumors were more prevalent in women (6 of 9 cases). The patients' median age was 46.4 years. The tumor was located in the cervical region in 7 patients $(78 \%)$ and in the lumbosacral region in 2 cases $(22 \%)$. The clinical syndromes produced by the tumors were nonspecific because of their spinal levels and their epidural position. Data pertaining to tumor characteristics and the results of surgery were analyzed. After confirming that stimulation of the distal part of the root of the tumor produced no response, the root giving rise to the tumor was sacrificed. Complete resection was achieved in all patients. Worsening of preoperative neurological deficits was observed in 2 patients : one patient, in whom the tumor capsule and surrounding connective tissues tightly adhered to the C5-7 nerves, and another patient, in whom the tumor capsule was very thin. Although their motor impairments have been improving over the 2 years since their operations, their neurological impairment continues to be worse than it was preoperatively. However, no recurrence was observed in all cases at 2-year follow-up. Based on our series of 9 surgically treated cases of spinal extradural schwannoma, it can be seen that sacrifice of the nerve root is often required to achieve total removal of the tumor, and that resection does not always result in a postoperative neurological deficit. Intraoperative stimulation can help the surgeon decide whether the root may be divided without incurring a postoperative deficit. With respect to tumor recurrence, complete resection of the tumor, including the tumor capsule, is preferred over intracapsular enucleation alone.
\end{abstract}

(Received : August 31, 2008 ; accepted : March 10, 2009)

\section{Key words}

spinal extradural tumor, schwannoma, surgery, nerve root, enucleation

\section{はじめに}

脊髄神経鞘腫は脊髄腫瘍のなかで最も多く，しかも硬 膜内䯣外に発生することが多く ${ }^{1,2)}$, 頸部腫瘤が初発症状 となり発見される症例も散見される。悪性のものは，正
確な頻度は不明であるがまれと考えられる。われわれは 2 年間で 9 例の脊䯣硬膜外神経鞘腫の手術症例を経験し, 手術と術後の神経所見の関連性について検討した。

*1 財団法人脳神経疾患研究所附属総合南東北病院脳神経外科 / T 963-8563 郡山市八山田 7-115〔連絡先：冨井雅人〕

Address reprint requests to : Masato Tomii, M. D., Department of Neurosurgery, Southern TOHOKU Research Institute for Neuroscience, Southern TOHOKU General Hospital, 7-115 Hachiyamada, Koriyama-shi, Fukushima 963-8563, Japan

*2 医療法人将道会総合南東北病院脳神経外科, *3 グローバルスパイン 
Table 1 Summary of our 9 cases of spinal epidural schwannoma

\begin{tabular}{|c|c|c|c|c|c|}
\hline Case & Age/Sex & Tumor origin & Pre OP Symptoms & Post OP Symptoms & Pathological diagnosis \\
\hline 1 & $41 / \mathrm{M}$ & $\begin{array}{l}\text { muscle branch of } \\
\text { right psoas muscle }\end{array}$ & - & - & neurofibroma \\
\hline 2 & $55 / \mathrm{F}$ & left L5 nerve & $\begin{array}{c}\text { left buttock's pain \& pain in } \\
\text { left } 1^{\text {st }} \text { toe }\end{array}$ & left L5 weakness and numbness & neurinoma \\
\hline 3 & $33 / \mathrm{F}$ & right C3 nerve & clumsiness in both $\mathrm{u} / \mathrm{e}$, & remission & neurinoma \\
\hline 4 & $70 / \mathrm{F}$ & left C7 nerve & numbness in left $2^{\text {nd }}$ finger & left $\mathrm{C} 5-7$ motor weakness $(3 / \mathrm{V})$ & neurinoma \\
\hline 5 & $35 / \mathrm{M}$ & bilateral $\mathrm{C} 2$ nerve & weakness in both legs & no change & neurinoma \\
\hline 6 & $64 / \mathrm{F}$ & $\begin{array}{l}\text { ant. branch of } \\
\text { right C3 nerve }\end{array}$ & - & - & neurinoma \\
\hline 7 & $62 / \mathrm{F}$ & left C5 nerve & - & - & neurinoma \\
\hline 8 & $33 / \mathrm{F}$ & right $\mathrm{C} 2$ nerve & $\begin{array}{l}\text { numbness in right posterior } \\
\text { region of neck } \sim \text { auricle }\end{array}$ & remission & neurinoma \\
\hline 9 & $25 / \mathrm{M}$ & left $\mathrm{C} 6$ nerve & $\begin{array}{c}\text { numbness from left shoulder } \\
\text { to } 2^{\text {nd }}-4^{\text {th }} \text { fingers }\end{array}$ & remission & neurinoma \\
\hline
\end{tabular}

\section{対象および方法}

2005 年 10 月 2007 年 9 月までの 2 年間に当科で経験 した脊䯣硬膜外神経鞘腫の手術症例は 9 例で, 年齢は 25 70 歳, 平均 46.4 歳で男性 3 例, 女性 6 例. 腫瘍の局在 は頸椎に 7 例, 腰椎に 2 例で, 症状は腫瘍の大きさや伸 展方向に応じて外表より腫瘤を触知する程度から神経根 症状を呈したものまであった（Table 1)。手術適応は原 則的に症候性例で，無症候性例に関しては経過観察画像 フォローとし, 神経学的症状の発現あるいは画像上腫瘍 増大が認められればその時点で手術適応とした。

\section{手術および結果}

手術は原則的に，術中電気刺激モニターを使用下に， 記録電極は腫瘍発生神経と考えられる神経の支配領域の 筋肉に装着した。たとえば $\mathrm{C} 6$ 神経由来と術前に考えれば, 同側の上腕二頭筋，腕橈骨筋，短母指屈筋に電極を装着 した。腫瘍は最初被膜内側から摘出し, 腫瘍の近位側, 腫瘍に移行しているところで腫瘍発生神経を切断したの ち，腫瘍被膜ごと全例全摘出した。症状は，術前後で神 経学的に不変であった症例が 4 例，術後症状が軽快ある いは消失例が 3 例（33\%）であったが，術後 2 例（22\%） に新たな神経症状の出現を認めた。 1 例は腫瘍被膜が正 常神経と強固に瘉着しており被膜を焼却凝固しながら摘 出した例（症例 4）でもう 1 例は腫瘍被膜がはっきりし なかった例（症例 2）であった（Table 1)。以下代表例 3 例を提示する。

\section{1 症例 7}

患 者: 62 歳, 女性

3 カ月来の左顎下部の腫瘤を自覚した．画像にて $4 / 5$ レベルで右 extraforaminal region に径 $2 \mathrm{~cm}$ の腫瘍を認め た（Fig. 1 a)。運動麻痺，感覚障害は認めなかったが腫 瘤を本人が自覚するようになり，腫瘍がこれ以上大きく なると右 C5 領域の神経症状が出現しうることから手術 を施行した。手術は触知する腫瘤の中心部分で皮虚割線 に沿って皮膚を切開して腫瘍にアプローチした。腫瘍の 頭側端は C2 レベルまで達しており内頸動脈と食道の間 で頸長筋腹側を尾側へ伸展しており腫瘍は右 C3 根糸の 筋枝から発生していた (Fig. 2 a, b). 腫瘍は全摘出で き，組織は神経鞘腫であった。術後神経学的に新たな症 状の出現を認めず，術後 1 力月後 MRI で腫瘍は全摘出

\section{されている (Fig. 1 b).}

\section{2 症例 9}

患 者: 25 歳, 男性

1 年来の左肩から左手第 2 指から第 4 指に 10 分間くら い持続する不定期なしびれにて発症した。神経学的には しびれ以外の異常所見は認めなかった。画像にて C $5 / 6$ レベルに，C6 の左神経根管，椎体，左横突起，左椎弓 根，C5/6 関節面を侵食，脊柱管内に伸展し硬膜外より春 䯋圧迫を伴う，春柱管外にも伸展する腫瘍を認めた（Fig. 3 a). 手術は左 C6, C7 片側骨形成椎弓切開術にてアプロー チし (Fig. 4 a)，腫瘍の減量により，腫瘍の頭側に腫瘍 被膜に接して存在する神経根を認め，電気刺激で C5, C6 支配筋である三角筋，上腕二頭筋および腕橈骨筋の筋 電図反応が高振幅で得られ，一方完全に腫瘍化した左 C6 神経根の直接電気刺激では C5，C6 支配筋の筋電図反 応は低振幅であったため，腫瘍は左 C6 神経後根発生で 


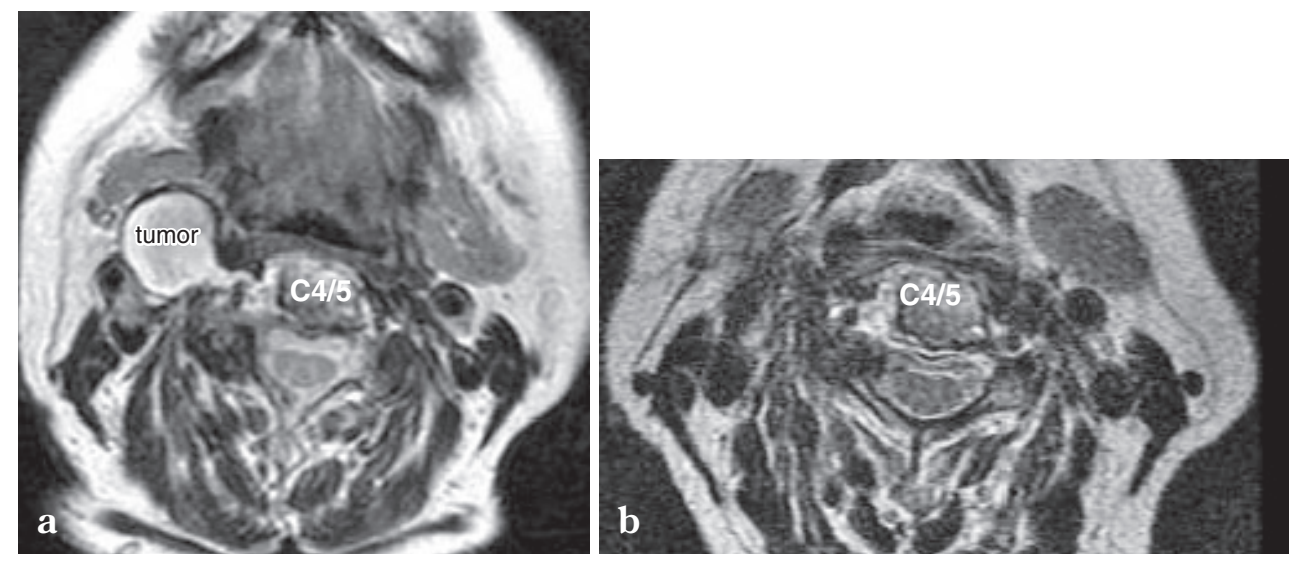

Fig. 1 Case 7

a : a preoperative axial $\mathrm{T} 2$-weighted magnetic resonance image (MRI) showing a $2-\mathrm{cm}$-long mass at the $\mathrm{C} 4 / 5$ level in the extraforaminal region on the right.

b : a postoperative axial T2-weighted MRI taken 1 month after operation reveals complete removal of the tumor.
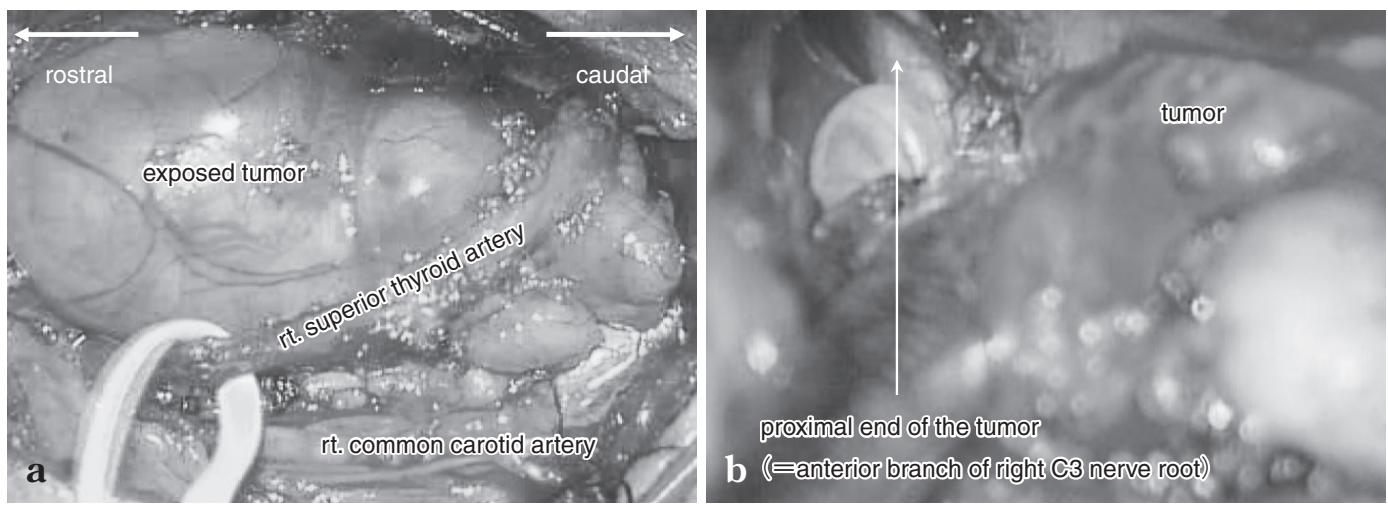

Fig. 2 Case 7

Intraoperative photographs showing the tumor extending to the $\mathrm{C} 2$ level at the rostral side (a), and the tumor originating from the muscle branch of the right $\mathrm{C} 3$ nerve root $(\mathbf{b})$.

あると判断して，神経根を含めて全摘出した（Fig. 4 b）. 組織は神経鞘腫であった。術後 3 力月後 MRI にて腫瘍 は全摘出されている (Fig. 3 b). 神経学的には術後より しびれは消失し 2 年後の現在も異常を認めず，画像にて も腫瘍の再発を認めていない。なお本例は多発性神経鞘 腫例で左脊椎傍筋肉内腫瘍も同時に摘出した.

\section{3 症例 4}

患 者：70 歳, 女性

10 年来左側前頸部に腫瘤を触れることを自覚，来院時 腫瘤の圧迫で左第 2 指のしびれを認めた。そのほかの神 経学的異常所見は認めなかった。画像にて左前頸部に一 部が左 $\mathrm{C} 6 / 7$ 椎間孔に進展する $5.5 \times 3.0 \mathrm{~cm}$ の占拠性病変 を認めた（Fig. 5 a, b). ${ }^{18}$ F-FDG-PET にて SUV（standardized uptake value) $\max$ が 7.2 と高值で悪性腫瘍が示
唆された $($ Fig. 5 d). 手術は触知する腫瘤の中心部分で 皮膚割線に沿って皮膚を切開して腫瘍にアプローチした。 腫瘍後方部は腕神経叢の上および中神経幹と腫瘍被膜お よび周囲の結合組織が高度に癒着していたが, 正常構造 物を腫瘍被膜から剝離した（Fig. 6 a). 腫瘍を中枢側へ 辿ると左 C7 神経根へ連続しており腫瘍発生神経と考え られた. 左 $\mathrm{C} 7$ 神経根の直接電気刺激では短母指屈筋お よび小指屈筋の筋電図反応は得られず，神経根を含めて 腫瘍を全摘出した (Fig. 6 b) 。組織は神経鞘腫で悪性所 見は認めなかった。 MIB-1 index も低值であった。術後 6 力月後の MRI で腫瘍の再発は認めていない（Fig. 5 c). しかし術後より左上肢の挙上が不能で, 肩関節外転の軽 度麻痺, 时の屈曲は徒手筋力テスト（MMT：manual muscle testing） $2 / 5$ の麻痺が出現した. 術後 3 カ月後で症状 

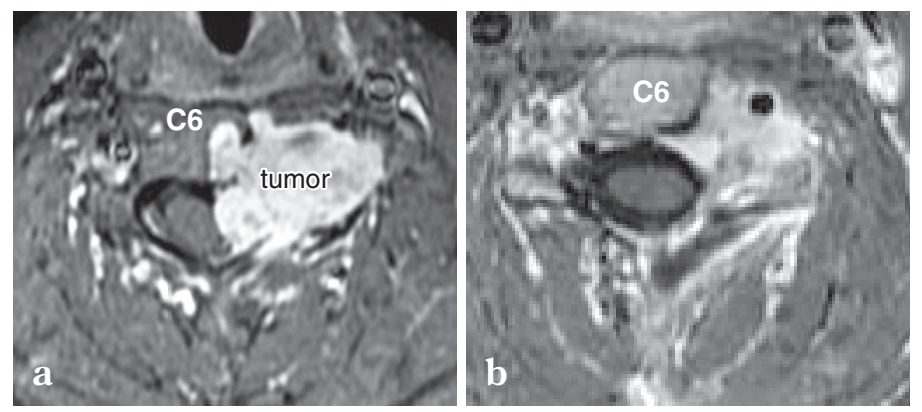

Fig. 3 Case 9

a : a preoperative axial $\mathrm{Gd}$-enhanced $\mathrm{T} 1$-weighted MRI showing an enhanced mass at the left C5/6 intra and extraforaminal canal with extraldural cord compression.

b : a postoperative axial $\mathrm{Gd}$-enhanced $\mathrm{T} 1$-weighted MRI taken 3 months after operation shows complete removal of the tumor.
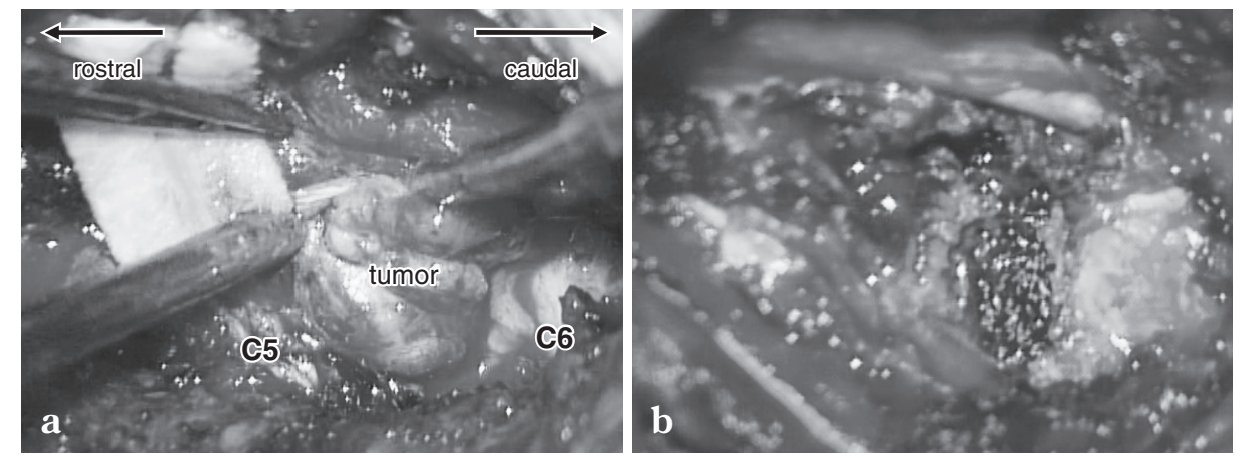

Fig. 4 Case 9

Intraoperative photographs show that the tumor originates from the left $\mathrm{C} 6$ nerve root $(\mathbf{a})$, and that this nerve was resected at the proximal end of the tumor (b).

は改善傾向となり，1 年後で上肢は水平位まで挙上可能, 1 年半後には MMT $4 / 5$ となった.

\section{考 察}

脊髄神経鞘腫は脊髄腫瘍中 $25 \%$ を占め最多で， $70 \%$ は 硬膜内髄外に発生することが多く硬膜内外にわたるもの が $15 \%$ で，硬膜外は転移性腫瘍が含まれる割合によって 15〜 $50 \%$ と幅がある ${ }^{1)}$. 部位は胸髄に $50 \%$, 頸髄に $25 \%$, 腰髄以下に $25 \%$ と胸䯣に多く, 大部分は後根から発生す る2). Dumbbel type は 25〜50\%で，C1，C2 神経根に発 生する率は $5 \%$ で2), George ら ${ }^{3)}$ の脊髄神経鞘腫 42 例の 報告では NF1, NF2 の患者が含まれて抢り多発性で硬膜 外発生が $38 \%$ と高い. また Lot ら ${ }^{4)}$ はすべての頸髄神経 鞘腫の $15 \%$ に硬膜外の腫瘍局在を認めるとしている。さ

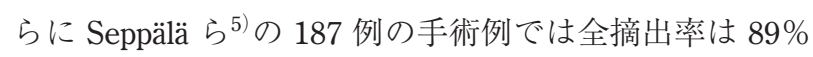
で，術後の神経症状の改善は $78 \%$, 不変 $15 \%$, 悪化 7\% と報告している.

われわれの症例から手術に際し, 腫瘍の発生した神経 を切断して術後神経学的脱落症状が発生しないか, そし てわれわれの症例では施行しなかったが手術は intracapsular enucleation（腫瘍被膜内摘出）で十分なのかについ
て考察する．腫瘍の発生した神経を切断して術後神経学 的脱落症状が発生しないかに関しては諸氏の報告がある. Celli $ら^{6)}$ の 24 例の硬膜外脊髄神経鞘腫の手術例では C 5 神経根を切除した 1 例を含めた計 2 例に永続的な根症状 を生じた. Donner ら ${ }^{7)}$ の末梢神経の 85 例の神経鞘腫, 197 例の神経線維腫の手術例で神経鞘腫に関しては手術で腫 瘍の近位側および遠位側の神経束を全摘出のため切除し たが術後神経学的脱落症状を生じなかった．Kim ら ${ }^{8)}$ は 脊髄神経鞘腫 31 例の手術例で神経根を腫瘍摘出のため 犠牲にしたが術後 7 例に軽度か一時的な神経脱落症状が 経験されたのみであった. そしてその機序は, 腫瘍の存 在する神経根はすでに機能を隣接根に移譲しており神経 根を切除しても脱落症状を起こさないとしている. Lot $ら^{4)}$ は頸椎の神経鞘腫 52 例（神経鞘腫 23 例, 神経線維 腫 29 例）の手術症例で 2 例以外全摘出でき, 叢状神経 線維腫の例と摘出した隣接 C5 神経根に再発した例の計 2 例のみ術後新たな神経脱落症状を呈した。ささらに Schultheiss $ら^{9)}$ は 42 例の脊髄神経鞘腫の手術のうち 10 症例で腫瘍発生神経を犠牲にしたが 4 例に一時的な麻痺 を生じたのみと報告している。このように腫瘍発生神経 の切除と術後の神経症状の出現に関してはなお議論の余 地がある。われわれの症例はすべて術中電気刺激モニター 

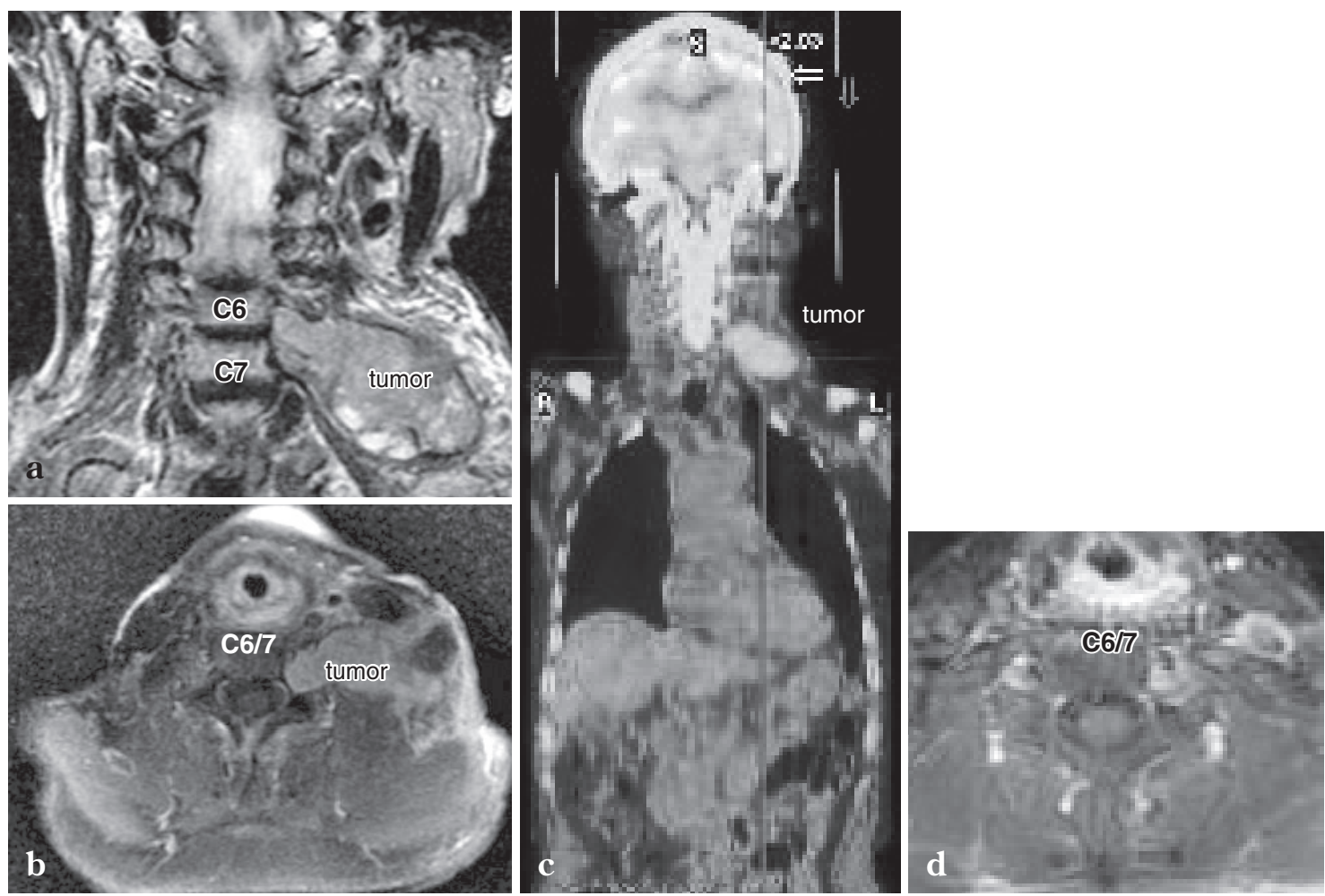

Fig. 5 Case 4

Preoperative sagittal T2-weighted MRI (a) and axial Gd-enhanced T1-weighted MRI (b) demonstrating a $5.5 \times$ $3.0 \mathrm{~cm}$ mass at the $\mathrm{C} 6 / 7$ level at the left extraforaminal region extending partially into the foramen.

c : a postoperative axial $\mathrm{Gd}$-enhanced T1-weighted MRI taken 6 months after operation reveals complete removal of the tumor.

d : preoperative coronal ${ }^{18} \mathrm{~F}-\mathrm{FDG}$-PET (positron emission tomography) image demonstrating high accumulation of FDG at the anterior cervical region on the left. SUV $\max =7.2$.
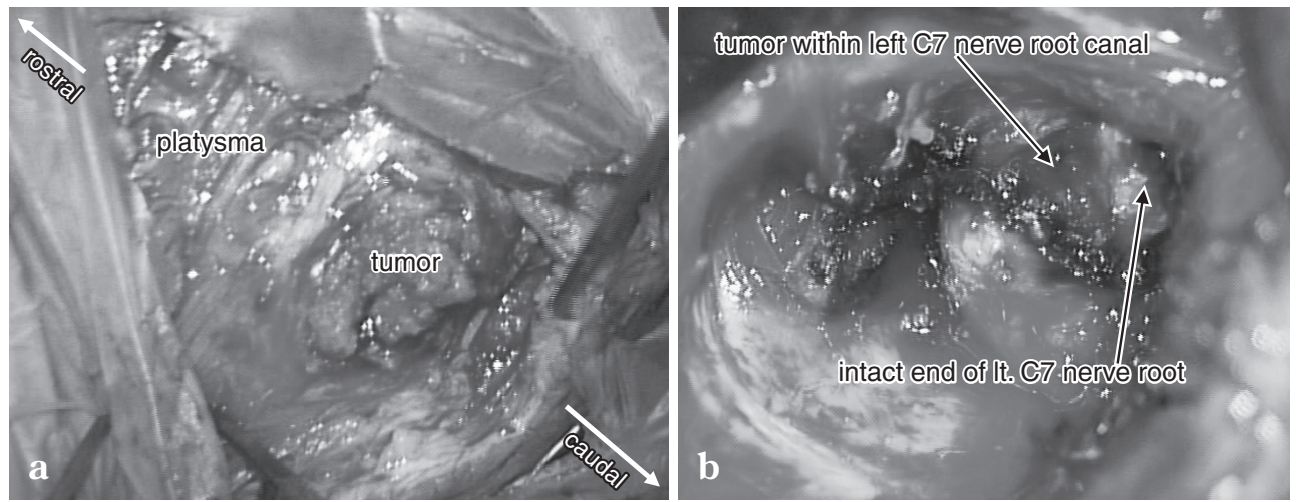

Fig. 6 Case 4

Intraoperative photographs show that the tumor capsule and the superior and middle trunks of the brachial plexus adhere strongly to the posterior part of the tumor $(\mathbf{a})$, and that the tumor originates from the left $\mathrm{C} 7$ nerve root $(\mathbf{b})$.

を使用し，Lot $ら^{4)}$ と同様の方法で腫瘍の神経根遠位の電 気刺激にて反応がないことを確認して神経を含め全摘出 した。もっともわれわれの 9 手術症例中，術後新たな神 経症状を生じた 2 例では神経を犠牲にしたことより，特
に症例 4 では神経と腫瘍被膜およびその周囲の反応性増 殖軟部組織が高度に癒着しており, それらの剝離がやや 困難で, 術後の新たな神経脱落症状出現の一因と考えら れた。文献およびわれわれの症例から, 術中腫瘍の神経 
根遠位の電気刺激にて反応がなければ，あるいはある程 度の反応があっても, 神経を含め全摘出しても術後神経 学的に軽度か一時的な神経脱落症状の出現程度であると 考えられる。ただ神経摘出にて著明な脱落症状が生じ うることは事実であり, 特に腫瘍が C5-T1 の上肢の運 動知覚と密接な関係のある症例では術中神経機能のモ二 タリングにて神経脱落症状の予知予防は必須である。

次に手術は腫瘍被膜内摘出で十分かどうかである. 長 谷川ら ${ }^{10)}$ は脊髄神経鞘腫の組織学的検索にて, 腫瘍被膜 は nerve tissue layer, fibrous layer および腫瘍細胞と線維 組織の混在した transitional layer の 3 層から構成され, 各層の境界は不明瞭で腫瘍と反応性結合組織である被膜 の境界は明瞭でないことなどから, 腫瘍被膜ごと摘出が 理想であるとしている。一方, Kuo ら ${ }^{11}$ は聴神経腫瘍の 場合であるが, 腫瘍被膜は腫瘍そのものが圧迫されて形 成されたもので腫瘍被膜内摘出のみでは腫瘍細胞が残存 するが，術後腫瘍への血流動態が変化し腫瘍への不十分 な血流にて再発することはまれと報告している，過去の 報告で言及はされておらず，また組織学的に検索した訳 ではないが，われわれの症例から腫瘍被膜の周囲には被 膜とは明らかに異なる, 比較的容易に剝離される反応性 の増殖軟部組織と考えられる構造物が認められる.よっ てわれわれの手術方法は反応性と考えられる周囲の軟部 組織を残存させるので, それを腫瘍被膜とすれば一般的 には被膜内摘出ということになるが, 腫瘍そのものの被 膜は摘出している。 よって当然その構造物を摘出する必 要性はないと考える。またわれわれの 9 症例で 2 年間の フォローでは再発を認めず, 過去の文献にても腫瘍被膜 内摘出で終わった症例で腫瘍再発が多いという報告はさ れていない ${ }^{12,13)}$. 以上より再発の観点から腫瘍の被膜を 含めた全摘出を目指寸べきであるが, 被膜が薄くなる神 経根管内の腫瘍, 静脈叢が発達した C1, C 2 レベルの腫 瘍や腫瘍被膜と正常構造物との癒着が高度で剝離が困難 な場合などでは, 可及的に被膜内からの腫瘍摘出で良好 な結果が得られると考えられる.今後われわれの症例で は検討しなかった組織学的検討を含め, 症例の長期的な フォローが必要である。

\section{結 語}

脊䯣硬膜外神経鞘腫の手術に際し, 腫瘍の発生した神 経を切断しても術後新たな神経学的脱落症状は発生する ことは少ないと考えられ，また腫瘍被膜が正常神経と癒 着し剝離が困難な場合などで術後神経学的症状が出現す る可能性が高いと考えられる場合は被膜内摘出も考慮さ れる。

\section{文 献}

1）続木陽子, 厚東篤生: 春髄硬膜内髄外腫瘍の病理. 脊椎 脊髄 $1: 355-365,1988$

2) 松谷雅生: 春髄腫瘍. 山浦晶編: 脳腫瘍. 東京, 篠原 出版, 1996, pp401-416

3) George B, Lot G : Neurinomas of the first two cervical nerve root: A series of 42 cases. J Neurosurg 82: 917-923, 1995

4) Lot G, George B : Cervical Neuromas with extradural components: surgical management in a series of 57 patients. Neurosurgery $41: 813-822,1997$

5) Seppälä MT, Haltia MJ, Sankila RJ : Long-term outcome after removal of spinal schwannoma : A clinicopathological study of 187 cases. J Neurosurg $83: 621-626,1995$

6) Celli P, Trillò G, Ferrante L : Spinal extradural schwannoma. J Neurosurg spine 2: 447-456, 2005

7) Donner TR, Voorhies RM, Kline DG : Neural sheath tumors of major nerves. $J$ Neurosurg 81:362-373, 1994

8) Kim P, Ebersold MJ, Onofrio BM, et al : Surgery of spinal schwannoma. J Neurosurg $\quad 71: 810-814,1989$

9) Schultheiss R, Gullotta G : resection of relevant nerve roots in surgery of spinal neurinomas without persisting neurological deficit. Acta Neurochir (Wien) 122: 9196, 1993

10) Hasegawa M, Fujisawa H, Hayashi $Y$, et al : Surgical pathology of spinal schwannomas: A light and electron microscopic analysis of tumor capsules. Neurosurgery 49: 1388-1393, 2001

11) Kuo TC, Jackler RK, Wong K, et al : Are acoustic neuromas encapsulated tumors? Otolaryngol Head Neck Surg $117: 606-609,1997$

12) Tsukigi M, Kubota $Y$, Iijima $Y$, et al : Retroperitoneal schwannoma extending into the intravertebral foramen. Urol Int $69: 75-77,2002$

13) Uchida $\mathrm{K}$, Baba H, Maezawa $\mathrm{Y}$, et al : Lumbosacral dumb-bell neurilemmoma approached by microsurgical interlaminar foraminotomy. A case report. Int Orthop 20:119-122, 1996 